\title{
Jews in the Papal States between Western Sephardic Diasporas and Ghettoization: A Trial in Ancona as a Case Study $\left(1555^{-1563)}\right.$
}

\author{
Serena DiNepi*
}

In recent years, the history of the Jews in Italy in the early modern era has been at the center of many studies that are beginning to painstakingly trace the affairs of this minority group within the major events of the period. Based on sources that have long been overlooked by studies on this subject and on a renewed scientific sensibility, a profile is beginning to emerge of a history built on a range of interactions between Jews and Christians, notwithstanding the centuries-old discrimination to which the second subjected the first. The phenomenon of the ghetto, which was without a doubt the most characteristic and significant experience of the period, is now being investigated "beyond" and "across" the walls. On to the well-known history of discrimination, marginalization, and the pressures of Catholic proselytizing, a narrative which is full of nuances is being superimposed, where, at the center, are the tumultuous relations between Christians and Jews and the infinite individual stories that animated them. In depth investigations of administrative, economic, and judiciary documents (including those of the Roman Inquisition), together with innovative studies of objects, collections, and libraries, as well as more traditional research on notary registries now portray a complex and stratified society, in continuous contact with the external world yet capable of firmly maintaining its otherness. If, on the one hand, this now flourishing historiography of the ghetto — which is even a bit "revisionist" — is finally

* This paper revolves in part around a mid-sixteenth-century trial, the documents of which are conserved in the Archivio di Stato di Roma. The events at the heart of this litigation (which lasted eight years) are presented in detail in my article: "Relazioni oltre le mura. Un processo ad Ancona all'epoca dei ghetti (1555-1563)," Special issue, Rivista di Storia del Cristianesimo 14, no. 1 (2017): 27-48. I am especially grateful to Professor Thomas Y. Cohen, who discovered these unique documents many years ago and who has been so generous to share them with other scholars. Furthermore, I would like to thank Dr. Luca Andreoni, Professor Bernard Dov Cooperman, and Dr. Martina Mampieri for their continuous support and precise suggestions on Jews and Ancona at that time. English translation by Paul M. Rosenberg.

(C) SERENA DI NEPI, 2019 | DOI:10.1163/9789004392489_012

This is an open access chapter distributed under the terms of the prevailing CC-BY-NC License at the time of publication. 
succeeding at putting the Jews "on the map" of Italian history, on the other hand the great attention paid to the position of the group in national affairs has, perhaps, contributed to relegating this research to the margins of the international discussion about Jewish history. ${ }^{1}$

The political fragmentation among states that characterized Italian history until 1861 plays an important role in this trend. Studies of the Jewish communities of central and northern Italy (after the final expulsions from Sicily and the south during the first half of the sixteenth century) have often assumed a local character, ultimately describing a history of ghettos and communities where each case seems to stand alone, always remaining separate and cut off from more general events. ${ }^{2}$ The evident disparity between the general conditions assured to the Jews from place to place and from time to time, which in turn were the result of ongoing negotiations on a dual track-the Jews with the authorities and the Jews with ecclesiastic institutions - translates into a history of infinite exceptions. It is a history of individual cities and individual communities, each with its leaders and its particular capacity to be a part of general events; but each also cut off from the rest of Jewish Italy and, as a consequence, from the rest of the Jewish world. In this fashion, the walls of the ghetto have ended up constructing the dominant interpretative view of Jewish

1 The massive bibliography on Italian ghettos has been consistently augmented in recent years. Among the most recent works, the majority of which are in Italian, see Luciano Allegra, Identità in bilico. Il ghetto ebraico di Torino nel Settecento (Turin: Zamorani Editore, 1996); Kenneth R. Stow, Theater of Acculturation. The Roman Ghetto in the 16th Century (Seattle, London: University of Washington Press, 2011); Marina Caffiero, Forced Baptism. Histories of Jews, Christians and Converts in Papal Rome (Berkeley: University of California Press, 2012); id., Legami pericolosi. Ebrei e cristiani tra eresia, libri proibiti e stregoneria (Turin: Eianudi, 2012); id., Storia degli ebrei nell'Italia moderna (Rome: Carocci, 2015); Stephanie Siegmund, The Medici State and the Ghetto of Florence. The Construction of an Early Modern Jewish Community (Stanford: Stanford University Press, 2006); Lucia Frattarelli Fisher, Vivere fuori dal ghetto. Ebrei a Pisa e Livorno (secc. XVI-XVIII) (Turin: Zamorani Editore, 2008); Marina Caffiero and Anna Esposito, eds., Gli ebrei nello Stato della Chiesa. Insediamenti e mobilità (secoli XIV-XVIII) (Padua: Esedra Editrice, 2012); Serena Di Nepi, Sopravvivere al ghetto. Per una storia sociale della comunità ebraica nella Roma del Cinquecento (Rome: Viella, 2013); Angela Groppi, ed., Gli abitanti del ghetto. La descriptio hebreorum del 1733 (Rome:Viella, 2014); Micol Ferrara, Dentro e fuori dal ghetto. I luoghi della presenza ebraica a Roma tra XVI e XIX secolo (Milan: Mondadori Università, 2015); Donatella Calabi, Venezia e il ghetto. Cinquecento anni del recinto degli Ebrei (Turin: Bollati Boringhieri, 2016); Giacomo Todeschini, La banca e il ghetto. Una storia italiana (Rome-Bari: Laterza, 2016); Marina Caffiero and Serena Di Nepi, eds., "I ghetti nell'Italia moderna." Special issue, Rivista di Storia del Cristianesimo 14, no. 1 (2017).

2 For an overview, see Marina Caffiero, Serena Di Nepi, "The Relationship between Jews and Christians. Toward a Redefinition of the Ghetto." Introduction to Special issue, Rivista di Storia del Cristianesimo 14, no. 1 (2017): http://primolevicenter.org/printed-matter/not-that-ghetto/. 
Italy, and obscuring for the modern era the paradigm of inter-Jewish networks and of uninterrupted mobility that has been convincingly proposed regarding medieval history by Michele Luzzati ${ }^{3}$ and by many others. ${ }^{4}$ Now, however, the scene is changing. On one side, there are important results emerging from investigations regarding relations between Jews and Christians, and, on the other, there is renewed attention on relations between Jews, within the Italian ghettos, but also and foremost outside the cramped confines of the pre-Unity regional States. ${ }^{5}$ Research on the circulation of books and objects, which is

3 Michele Luzzati outlined the convincing paradigm on Jewish mobility and Christian-Jewish interactions in Italy in the Middle Ages and the Renaissance in a multitude of articles and books. Among them La casa dell'ebreo. Saggi sugli ebrei a Pisa e in Toscana nel Medioevo e nel Rinascimento (Pisa: Nistri Lischi, 1985); "Banchi e insediamenti ebraici nell'Italia centrosettentrionale fra tardo Medioevo e inizi dell'Età moderna," in Storia d'Italia, Annali 11, Gli ebrei in Italia, ed. Corrado Vivanti, vol. 1, Dall'alto Medioevo all'età dei ghetti (Turin: Einaudi, 1996): 175-235; "Una famiglia e quattro cognomi toponimici nel corso di un secolo: contributo alla storia degli ebrei d'Italia nel tardo Medioevo in una prospettiva interlocale," in Quel mar che la terra inghirlanda. In ricordo di Marco Tangheroni, ed. Franco Cardini and Maria Luisa Ceccarelli Lemut (Pisa: Pacini 2007): 469-77; with Giuliano Lazzarini, "Lorizzonte "italiano" di una famiglia ebraica laziale: prime note sui da Toscanella," in Gli ebrei nello Stato della Chiesa. Insediamenti e mobilità, secc. XIV-XVIII, ed. Marina Caffiero and Anna Esposito (Padua: Esedra, 2012), 51-62. For an outline of his important work within the frame of both general history and Jewish history, see Alessandra Veronese, "Michele Luzzati e la storia degli ebrei come specchio della storia medievale," in "Diversi angoli di visuale" fra storia medievale e storia degli ebrei. In ricordo di Michele Luzzati, ed. Anna Maria Pult Quaglia and Alessandra Veronese (Pisa: Pacini Editore, 2016), 59-71.

4 On this topic, see at least a short selection of classical works: Ariel Toaff, Il vino e la carne. Una comunità ebraica nel Medioevo (Bologna: Il Mulino, 1989); Robert Bonfil Rabbis and Jewish Communities in Renaissance Italy (Oxford: Oxford University Press, 1990); and Anna Esposito Un'altra Roma. Minoranze nazionali e comunità ebraiche tra Medioevo e Rinascimento (Rome: Il Calamo, 1995). Most recently, Alessandra Veronese, Una famiglia di banchieri ebrei tra XIV e XVI secolo. I da Volterra: reti di credito nell'Italia del Rinascimento (Pisa: ETs, 1998); Rachele Scuro, "La presenza ebraica a Vicenza e nel suo territorio nel Quattrocento," Reti medievali rivista 6, no. 1 (2005): http://www.rm.unina.it/rmebook/dwnld/ebrei/Ebrei_07_Scuro.pdf; Mafalda Toniazzi, I Da Camerino: una famiglia ebraica italiana fra Trecento e Quattrocento (Teramo: Palumbi, 2015); Miriam Davide and Pietro Ioly Zorattini, eds., Gli Ebrei nella storia del Friuli Venezia Giulia. Una vicenda di lunga durata (Florence: Giuntina, 2016); Pierre Savy, "Les 'politiques juives' en Italie du Nord avant les ghettos," in Religious Minorities, Integration and the State. État, minorités religieuses et integration, ed. Ivan Jablonka, Nikolas Jaspert, Jean-Philippe Schreiber and John Victor Tolan (Turnhout: Brepols, 2016), 35-47; and "Entre peuple et communauté: remarques sur l'idée de nation chez les Juifs d'Italie $\left(\mathrm{XV}^{\mathrm{e}}-\mathrm{XVI}{ }^{\mathrm{e}}\right.$ siècles)," Revue de l'histoire des religions 234, no. 2 (2017): 297-314. The Lexicon directed by Shlomo Simonsohn also offers a summary of Jewish history in Italy on a geographical basis, from antiquity to the present: http://www7.tau.ac.il/omeka/italjuda/.

5 The series Documentary History of the Jews in Italy offers a wide range of sources in Latin, Hebrew and Italian translated into English; as a result, it is often possible to follow people day 
a subject that in large part remains unexplored, is bearing first fruits in this direction, revealing how, exactly, the connections across the wall constitute a central (and until now neglected) aspect of the history of the Italian ghettos in the modern era. ${ }^{6}$

The impact of the Western Sephardic diasporas on Jewish Italy, in turn, plays a role, at least in part, in this discussion. Studies on the arrival of the Sephardim have achieved their best results concerning Ferrara and Venice in the early 150os, starting from the saga of Dona Gracia Nasi and on, thanks to the extraordinary work undertaken in the archives of the Estense city by Aron di Leone Leoni. ${ }^{7}$ In general, and outside of these small exceptional cases, investigations are concentrated on the moment of settlement and the first checks on the religious identities of the refugees, emphasizing their hybrid allegiances and their negotiations with power at many levels. Furthermore, at least for the period of the 150os, great attention has been dedicated to the cultural ferment and to the innovations brought by the Spanish and Portuguese, who, arriving in Italy during the golden era of Hebrew printing, knew how to contribute to it in a significant way. In this case as well, however, a local interpretation has prevailed, centered on the paradigm of the exceptional benevolence or extraordinary aversion of Princes and Cities; as a result, the broader importance of these events has been overshadowed, both with respect to the

by day and generation by generation. See for now Shlomo Simonsohn, The Jews in the Duchy of Milan, 4 vols. (Jerusalem: The Israel Academy of Science and Humanities, 1982-1986) and The Jews in Sicily, 18 vols. (Leiden: Brill, 1997-); Renata Segre, ed., The Jews in Piedmont (Jerusalem: The Israel Academy of Sciences and Humanities, 1986-199o); Ariel Toaff, ed., The Jews in Umbria (Leiden: Brill, 1992-1994); Rossana Urbani and Guido N. Zazzu, eds., The Jews in Genoa (Leiden: Brill, 1999); Kenneth R. Stow, ed., The Jews in Rome, 1536-1551 (Leiden: Brill, 1995-1996).

6 See Joseph R. Hacker and Adam Shear, eds., The Hebrew Book in Early Modern Italy (Philadelphia: University of Pennsylvania Press, 2011); Scott Mandelbrote and Joanna Weinberg, eds., Jewish Books and Their Readers. Aspects of the Intellectual Life of Christians and Jews in Early Modern Europe (Leiden: Brill, 2016). See also the journeys of books and culture outlined by the Italian entries in the project: Footprints. Jewish Books through Time and Place: https://footprints.ccnmtl.columbia.edu.

7 See the monumental collection by Pier Cesare Ioly Zorattini, ed., Processi del S. Uffizio di Venezia contro ebrei e giudaizzanti (Florence: Olschki, 1980-1999). Most recently, Robert C. Davis and Benjamin Ravid, eds., The Jews of Early Modern Venice (Baltimore; London: Johns Hopkins University press, 2001); Federica Ruspio, La nazione portoghese. Ebrei ponentini e nuovi cristiani a Venezia (Turin: Zamorani, 2007); Aron di Leone Leoni, La nazione ebraica spagnola e portoghese di Ferrara (1492-1559). I suoi rapporti col governo ducale e la popolazione locale ed i suoi legami con le nazioni portoghesi di Ancona, Pesaro e Venezia, ed. Laura Graziano Secchieri (Florence: Olschki, 2011); Pier Cesare Ioly Zorattini, Michele Luzzati and Michele Sarfatti, eds., Studi sul mondo sefardita. In memoria di Aron Leoni (Florence: Olschki, 2012). 
overall phenomenon of the Western Sephardic diasporas and with respect to their interest, at the same time, as the cause of Sephardic settlement across a large majority of the lands of Italy. Yet, if one begins to observe with attention the life of the communities who were called upon to contend with the Sephardim, even over a long time and in fully functioning ghettos, themes and problems emerge which are less uniquely Italian than is too often imagined. Questions related to relations between the Sephardim and the local Jews, to the formation of relations with Christian institutions and society, to the role of a group of cultural, familial, and economic international networks, and to the conduct between Jews, as well as between Jews and non-Jews permit, in fact, the productive insertion of Italian affairs into this markedly global history. ${ }^{8}$ The work of Francesca Trivellato on the international and intercultural commerce to and from Livorno in the 170os, after all, speaks for itself. ${ }^{9}$

Based on the analysis of a case study from Ancona, this article proposes to reason precisely along these lines, concentrating on the difficult years that accompanied the publication of the papal bull Cum nimis absurdum. The breaking of an engagement that was celebrated in the winter of 1555 (and therefore in the months which preceded the birth of the ghettos and the opening of proceedings against Marranos), and the lengthy legal controversy that followed it, which was argued in front of a regular Christian magistracy between 1555 and 1563, offers ideas for an effort to answer important questions: What relations were there, if any, with Jews who lived outside the national borders? Is it possible to recognize behaviors typical of the many other communities involved in the Western Sephardic diasporas within the ghettos of the Papal States as well? What was the reaction of Italian Jewry to the process of ghettoization?

The article begins with the problems encountered in Italy, and in the Papal States in particular, between 1492 and 1493, when the old regional States had to make difficult decisions regarding Jewish refugees in search of welcome.

8 A tiny group of innovative works is paving this way. See Luca Andreoni, ed., Ebrei nelle Marche. Fonti e ricerche (secoli $X V-X I X$ ) (Ancona: Il lavoro editoriale, 2012); Luca Andreoni, "'Sono molto delicati li Ebrei di questo ghetto.' Conversioni e strategie di difesa degli ebrei ad Ancona e nella marca pontificia (secoli XVII-XVIII)," Materia Giudaica 19 (2014): 291-302; Evelyne Chayes and Giuseppe Veltri, Oltre le mura del ghetto. Accademie, scetticismo e tolleranza nella Venezia barocca (Palermo: New Digital Press, 2016); Paolo Pellegrini, ed., Presenza ebraiche in Umbria dal Medioevo all'età contemporanea (Perugia: Editoriale Umbra, 2017); Benedetto Ligorio "Ragusa. Un ghetto solo mercantile in Adriatico orientale (1546-1667)"; and Nourit Melcer Padon, "Free Jews in a Free Port City: Livorno, The City without a Ghetto," both in the special issue of Rivista di Storia del Cristianesimo 14, no. 1 (2017):53-70 and 71-88, respectively.

9 Francesca Trivellato, The Familiarity of Strangers. The Sephardic Diaspora, Livorno, and CrossCultural Trade in the Early Modern Period (New Haven: Yale University Press, 2010). 
The second section presents the Ancona trial, with a focus on the question of the building of trust and of good conduct by the Jews, and then returns to the general subject, and to the possibility of re-reading the events of the 1500 s from a perspective that finally weaves the birth of the ghetto and the diasporas of the Sephardim into the larger history of these years, between wars in Italy, and the explosion of the Protestant reform.

Papal States, the Pope and the Jews in the Sixteenth Century: The Sephardic Issue in Context

Beginning in the summer of 1492 and increasing in the following years, waves of Jewish refugees, first from Spain and Sicily, and then from Portugal, sought refuge in Italian cities. ${ }^{10}$ With the arrival of the Sephardim, the communities of the Italian peninsula and the Christian authorities found themselves facing a demanding test. ${ }^{11}$ The fall of Charles VIII in Italy in 1494 and the opening of the French-Spanish conflict for supremacy on the peninsula made the decision to grant or refuse welcome to the exiles a diplomatic and political issue of great relevance. It is worth summarizing the principal aspects of this issue. On the political level, on one hand, the explicit rejection of Spanish policy regarding the Jews would have displeased Iberian royalty at a time when they were preparing military action for supremacy on the peninsula; on the other hand, taking this position could have been read as a signal of openness toward the French and, therefore, Venice. Internally the Italian Jews themselves did not underestimate the problem, and they well understood the general environment into which the requests of their brethren would enter, and the impact that these might have, fearing the opening of Iberian style investigations into the faith and identity of the migrants.

Between 1493 and 1494, Spanish Pope Alexander VI's decision resolved, in part, these doubts. The fugitives were admitted to Rome and the Papal States without a formal measure and notwithstanding the objections of the

10 For a general picture on the Iberian expulsions and on their consequences, see Anna Foa, The Jews of Europe after the Black Death (Berkeley and Los Angeles: University of California Press, 200o); Yosef Kaplan, An Alternative Path to Modernity. The Sephardic Diaspora in Western Europe (Leiden: Brill, 200o); Yosef Kaplan, ed., The Dutch Intersection. The Jews and the Netherlands in Modern History (Leiden: Brill, 2008); David Ruderman, Early Modern Jewry. A New Cultural History (Princeton, NJ: Princeton University Press, 2010).

11 For the arrival of Sephardim in Italy, see Caffiero, Storia degli ebrei nell'Italia moderna, 77-93. 
ambassadors of the Catholic Kings. ${ }^{12}$ The tacit hospitality that was accorded to the Spanish Jews at that juncture clearly demonstrated what Borgia's position was regarding the delicate subjects of the management of religious minorities, and which proselytizing strategies to employ when dealing with the most recalcitrant among the groups of infidels. ${ }^{13}$ At least for the moment, the Pope declared, the Iberian approach would not be replicated elsewhere. Though avoiding open conflict with Spain (while the winds of war blew over half of Italy), Alexander vi reiterated that the final word on the Jews and all things Jewish came from Rome, and that the Church would never accept the delegation of any aspect of the subject to others. The coincidental timing between the settlement of the Sephardim in the capital of the Papal States and the drafting of the so-called Bull of Donations raises important questions (which are still overlooked by historiography). In both cases, in fact, different considerations weighed and interacted, related as much to the State, with its borders and its temporal interests, as to the universal mission of the Church itself. On the one hand, there was Italian politics, where among dynastic quarrels and impossible balances the Pope played a dangerous game through his own son, as Niccolò Macchiavelli told us. ${ }^{14}$ On the other, there was the ongoing effort to protect the autonomy and universal authority of the Church, and therefore of the States which it governed and the spiritual subjects which it claimed as its own. ${ }^{15}$

From this point of view, the period of the fifteenth to the sixteenth century in Rome proves to be of great interest for the history of the Jews. Major historical trends compelled the Pope and the Church to have to reckon very quickly with each new manifestation of religious otherness, at the theoretical level as well as in the daily governing of the Pontifical lands. The Jews had to reckon with their ancient community and the Spanish emergency. Muslims had to deal with war at sea and the ever more aggressive policy of the Turks. Obviously, the discovery of the new American peoples, ignorant and wild but ready (with a bit of pressure) to welcome the Good News of the Evangelist was

12 Anna Foa discussed this topic in depth. See "Il nuovo e il vecchio: l'insorgere della sifilide (1494-1530)," Quaderni storici 19, no. 55 (1984): 11-34; "Un vescovo marrano: il processo a Pedro de Aranda," Quaderni storici 99 (1998): 533-551; "La prospettiva spagnola: il papa e gli ebrei nell'età di Carlo V," in L'Italia di Carlo V. Guerra, religione e politica nel primo Cinquecento, ed. Francesca Cantù and Maria Antonietta Visceglia (Rome: Viella, 2003), 509-22. Most recently, James Nelson Novoa investigated the settlement by Portuguese refugees and conversos: Being the Nação in the Eternal City. New Christian Lives in SixteenthCentury Rome (Peterborough: Baywolf, 2014).

13 Foa, "La prospettiva spagnola."

14 The protagonist of The Prince was Cesare Borgia, the Duke of Valentinois and the illegitimate son of the Pope Alexander VI.

15 Di Nepi, Sopravvivere al ghetto, 24-25. 
another important development. The central issue was the unresolved matter of the conversion of the infidels, the strategies for which were being modified based on current experiences but also, clearly, on results achieved up to that time. Thus, the Church had to evaluate cases of baptisms, successful and unsuccessful. At their disposal was a fifteen-hundred-year history of converting infidels, most of them Jews. This rich historical background furthermore demonstrated how less traumatic options than expulsion or violence could be viable. This expanded perspective clarifies, then, the serious considerations that pushed Alexander vi to take the path of silent compromise. The result was that the Sephardim settled in the holy city, but without causing disruptive rifts with the Spanish monarchy. Subsequently this model of quiet tolerance became a possible, and perhaps even desirable, model to export to the rest of the peninsula.

The explicit aversion of the local Jews is the other side of this history. Ibn Verga, in his celebrated account, offers a picture of the severe reaction of the Roman Jews and of the failed attempt of the community leaders to buy off the hostility of Alexander VI in gold. The decades long discussion regarding how much veracity should be granted to this passage has ended up limiting studies on the impact of the Western Sephardic diasporas in the Papal States to the first phase of this history, thus obscuring the political and ideological questions of general importance which doubtlessly guided the choices and solutions adopted in those years. ${ }^{16}$ Whatever interpretation one wishes to give

16 There are contrasting opinions, many scholars, and a multitude of research on this topic. Ariel Toaff stressed both the factionalism of the author and the sad feelings that he had to deal with: "Gli ebrei a Roma," in Storia d'Italia, Annali n, Gli ebrei in Italia, ed. Corrado Vivanti, vol. 1, Dall'alto Medioevo all'età dei ghetti (Turin: Einuadi, 1996), 123-52, esp. 148. Robert Bonfil pointed out the impossibility of embracing Ibn Verga's narrative as historical truth, asserting that it should be regarded as a clue to Sephardic sufferings: "How Golden Was the Age of Renaissance in Jewish Historiography?" in id., Cultural Change among the Jews of Early Modern Italy (Farnham: Ashgate, 2010), 85. On the contrary, Kenneth Stow highlighted the literary elements of this famous account: "Prossimità o distanza: etnicità, sefarditi e assenza di conflitti etnici nella Roma del sedicesimo secolo," $L a$ Rassegna Mensile di Israel 58, nos. 1-2 (1992): 61-74. For a general outline on the arrival of Sephardic refugees in Rome, see Simon Schwarzfuchs, "Controversie nella Comunità di Roma agli inizi del secolo XVI," in Scritti in memoria di Enzo Sereni, ed. by Daniel Carpi, Attilio Milani, and Umbero Nahon (Jerusalem: Fondazione Sally Mayer, 1970), 95-100 (Italian part); Ariel Toaff, "Lotte e fazioni tra gli ebrei di Roma nel Cinquecento," Studi romani 27 (1979): 25-32; Anna Esposito, "The Sephardic Communities in Rome in the Early Sixteenth Century," Imago temporis. Medium Aevum 1 (2007): 177-85; Bernard Dov Cooperman, "Ethnicity and institution building among Jews in Early Modern Rome," AJs Review 30 (2006): 119-45; and "Licenses, Cartels, and Kehila. Jewish Moneylending and the Struggle against Restraint of Trade in Early Modern Rome," in Purchasing Power. 
it, the fact remains that the literary topos of Jewish misfortunes-which Ibn Verga shrewdly used to emphasize what place the expulsion from Spain had in the destiny of the people of Israel-finds indisputable confirmation in the documentation of the Christian notaries. As Anna Esposito has clearly demonstrated, in fact, the Sephardim as a group remained separate from the Roman Jews both in the organization of their synagogues and, on the other hand, in their daily lives, with their businesses and their commitments. Starting in 1496, the Spanish established a Communitas hebreorum hispanorum in Urbe commorantium, which in the following years became the model for the Communitates and Universitates that were similarly created by other foreign groups in the first decade of the 150os: Germans, French, and, naturally, Sicilians, as well as by the subgroupings of the Spanish themselves as Aragonese, Castilian, or Catalan. ${ }^{17}$ This situation was fertile ground for the rise of a tangle of legal conflicts over the distribution of taxes and regarding the modes of representation of the Jews to the pontifical institutions. Finally, in 1524, thanks to a decisive intervention by Pope Clement VII, the Jews who lived in Rome-whatever their origin might be - were given a statute which was destined to last for centuries. The famous Capitoli di Daniel da Pisa, which were issued with a brief pontifical, resolved the question, organizing political representation based on the edoth, but also (and above all) on the fragmented social composition of the community, in which the bankers obtained a position of absolute prominence. ${ }^{18}$

Three years later, the Sack of Rome once again rearranged the cards on the table. During nine months of occupation, the city was first put to steel and fire and then struck by the plague. The Jews suffered equally with the other inhabitants of Rome, to the point where it became difficult to find the ten

The Economics of Modern Jewish History, ed. R. Kobrin and Adam Teller (Philadelphia: University of Pennsylvania, 2015), 27-45. For a different opinion, see the numerous works by Kenneth Stow and especially “Ethnic Rivalry or Melting Pot: The 'Edoth' in the Roman Ghetto," Judaism 41 (1992): 286-96 and Theater of Acculturation, 24-25.

17 Among her vast scholarship on this topic, see Anna Esposito, "The Sephardic Communities in Rome in the Early Sixteenth Century"; "Gli ebrei di Roma prima del ghetto: nuovi spunti," in Monaci, ebrei, santi. Studi per Sofia Boesch Gajano, ed. Antonio Volpato (Rome: Viella, 2008): 377-94; and "Conflitti interni alla comunità ebraica di Roma tra Quattro e Cinquecento," in Judei de Urbe. Roma e i suoi ebrei: una storia secolare, ed. Marina Caffiero and Anna Esposito (Rome: Ministero per i Beni e le Attività Culturali, 2011), 69-79.

18 See the text of the Capitoli in Attilio Milano, "I Capitoli di Daniel da Pisa e la comunità di Roma," La Rassegna Mensile di Israel 10, nos. 7-8 (1935): 324-38 and 10, nos. 9-10 (1936): 409-26. I am currently working on a new edition of the text with Bernard Dov Cooperman and Anna Esposito, and it will be based on new sources. For a quick presentation of the topic, see Cooperman, "Ethnicity and Institution Building among Jews in Early Modern Rome," 124, n. 10; and Cooperman, "Licenses, Cartels, and Kehila," n. 36; Di Nepi, Sopravvivere al ghetto, 29-33. 
men necessary for a minyan, and families once divided by traditional enmities found themselves forced, by the state of things, to pray together. ${ }^{19}$ The devastation of those days left lasting traces, which surely played a role in the overcoming of old rifts. ${ }^{20}$ Although with our current knowledge it is not possible to draw an exact demographic picture of the community after 1527, the trauma of the Sack cannot be underestimated and should serve as a watershed moment for any research on the relations between edoth, starting with, obviously, the always interesting studies on matrimonial strategies as well as the strategies for transmitting and conserving estates. ${ }^{21}$ The years that followed the Sack were marked by the long papacy of Paul III Farnese, and by bad relations between the Pope and Charles v. The Emperor, committed on at least three fronts (Italy, Germany, and the Mediterranean), had hoped to find in the Pope an ally, but instead he found an indomitable rival, intent on defending the Papal States, and, most of all, the ascent of the Farnese. There was a decades long struggle between the Italy of the Pope and the Italy of the Emperor - according to Elena Bonora's useful definition - which involved the material consideration of the political destiny of the peninsula as much as it did the spiritual consideration of the fate of the Church after the outbreak of Protestantism. ${ }^{22}$ In this context, the Italian Jews, while not at the center of the authorities' attention (the countering of heresy and political dissent was considered to be more urgent), found themselves living in a time of convulsive transition: 1541 , the final expulsion from the Kingdom of Naples and the enlarging of the Ghetto of Venice; 1542, the institution of the new Congregation of the Holy Office; 1543, the opening of the Casa dei Catecumeni of Rome; 1543-1544, the imposition of the double tax on the Jews of the Papal States for the war against the Turks, and so on. ${ }^{23}$

Just a few years later, the publication of the bull Cum nimis absurdum and the establishment of Venetian-Ragusan style ghettos in the Papal States seemed to

19 Toaff, Gli ebrei a Roma, 152.

20 For instance, in 1555 the long-lasting consequences of 1527 were part of a trial that involved the family of the famous Rabbi Ovadiah Sforno: Di Nepi, Sopravviere al ghetto, $5^{2-}$ 75. The first trial against the Sforno family dated back to the years 1548-1555; see Micaela Procaccia, "Non dabarà.' Gli ebrei di Roma nelle fonti giudiziarie della prima metà del Cinquecento, in Italia Judaica VI, Gli ebrei nello Stato Pontificio fino al Ghetto (1555) (Rome: Ministero per i Beni e le Attività Culturali, 1998), 80-93.

21 For a general outline on Roman Jewish demography in the eighteenth century, see Michael Gasperoni, "Note sulla popolazione del ghetto di Roma in età moderna: lineamenti e prospettive di ricerca," in Groppi, Gli abitanti del ghetto, 69-115.

22 Elena Bonora, Aspettando l'imperatore. I prinicipi italiani tra il papa e Carlo V (Turin: Einaudi, 2014).

23 See Caffiero, Storia degli ebrei in Italia, 95-115, with updated and complete references to recent scholarship. 
settle things. Pope Paul IV Carafa decided that the Jews would be welcomed, but in a limited way, and among a host of discriminations, in the expectation that they would ultimately present themselves at the baptismal font. Historiography has long discussed the reasons behind this decision, at times insisting that it was fully attributable to the theological line of discrimination adversus iudaeos, which dated back to Augustine, ${ }^{24}$ and at times emphasizing the growing weight of the pressure for the conversion of the Jews during this period. ${ }^{25}$ However one wishes to see it, it is irrefutable that the publication of the bull served to clarify, once and for all, what the Pope's position was on the subject, and how that position stood firmly within the Catholic tradition of well thought out discrimination: the Jews had a place within Catholic society but, in the logic of the time, could not have been treated otherwise than being forced into a space built on humiliation and marginalization. ${ }^{26}$ From this moment on, for more than three centuries, the Jews continued to live as Jews in Central Italy, in their condition as guests who were somewhat unwelcome to a hostile majority. With the birth of the ghettos, this state of familiar otherness, regulated by shared rules, was reinforced, but without leading to an absolute separation between Jews and Christians. The rules of discrimination and humiliation constituted the unspoken foundation around which the interactions between majority and minority would develop. From 1555 and on, the porosity of the walls of the ghetto, which after all was fully expected by the law that had created them, permitted the survival of the same networks of relations between Jews and Christians and among the Jews themselves that had animated the preceding period and in which, certainly, the Sephardic networks continued to play a role in the Papal States and in Italy exactly as they did in the rest of the Jewish world.

24 Kenneth R. Stow, Catholic Thought and the Papal Jewry Policy (New York: The Jewish Theological Seminar of America: 1977), with an English translation of the bull and of other relevant Catholic sources since the Middle Ages.

25 Caffiero, Storia degli ebrei in Italia, 100-2, 112-16 and Forced Baptisms. For an outline of the Catholic perspective on Jews and the development of Anti-Judaism in Italy in the midsixteenth century, see Piero Stefani, L'antigiudaismo. Storia di un'idea (Roma-Bari: Laterza, 2004), 163-96. See also Renata Segre, "La Controriforma: espulsioni, conversioni, isolamento," in Storia d'Italia, Annali 11, Gli ebrei in Italia, ed. Corrado Vivanti, vol. 1., Dall'alto Medioevo all'età dei ghetti (Turin: Einaudi, 1996), 709-78.

26 For a discussion on the consequences of the Cum nimis absurdum in the rest of Italy, see David Berger, "Cum Nimis Absurdum and the Conversion of the Jews," Jewish Quarterly Review 70, no. 1 (1979): 41-49; Benjamin Ravid, "Cum Nimis Absurdum and the Ancona Auto-da-Fé Revisited: Their Impact on Venice and Some Wider Reflections," Jewish History 26 (2012): 85-100. 
In recent years, historiography has paid much attention to the Jewish/ Christian relationship, unequivocally demonstrating its long duration and complexity. The other side of the subject — and that is the relations among the Jews themselves and their behavior as Jews_instead remains partially in the shadows, especially regarding the Papal States. The question in search of an answer is this; to what extent did ghettoization - which was, obviously, a specifically Italian phenomenon ${ }^{27}$-result in a consistent and measurable exceptionality in the history of the Italian Jews, as compared with Jews elsewhere. From this perspective, a critical reevaluation that contextualizes the ghettos and the Sephardic diasporas together can yield one of the keys to a reading that is more significant, and until now more overlooked. The Anconian case study I present here offers points for such a reading, revealing how it is possible to insert the story of the ghettos within that of the Western Sephardic diasporas (and vice-versa), even outside the scope of the celebrated investigations of the first phase of the Spanish and Portuguese settlement and of the burning of the Marranos of Ancona.

A Trial and a Ghetto under Construction: Ancona $\left(1555^{-1563)}\right.$

In the winter of 1555 , the messenger of the Italian synagogue made the rounds of the Jewish quarter of Ancona to invite anyone who so desired to attend the celebration at the home of Yacob Belcayro in honor of his daughter Sara's engagement to Emanuel Montolmo. It was a happy occasion and many accepted the offer. Dancing, music, and good food accompanied the ceremony, and the two youths committed to tying the knot in the presence of Rabbi Yohannan Treves and a good part of the Jews of Ancona. To seal the pact, the girl was given a precious necklace and the families spent a pleasant evening together making plans for the future. Then something changed, and the father of the bride decided to break the pact, declaring himself prepared to pay the penalty prescribed in such cases. The groom and his family contested the decision, and undertook a lengthy legal proceeding to demonstrate that the ceremony of 1555 had been a genuine marriage ceremony and not the simple drawing up of only kiddushin. ${ }^{28}$

27 Todeschini, La banca e il ghetto; Caffiero, Di Nepi, "The Relationship between Jews and Christians."

28 Archivio di Stato di Roma, Tribunale Criminale del Governatore, Processi, 84, case 1, Anconitanis falsitatis hebreorum contra Jacob Bel Cayri hebreum [hereafter: Trial]. The trial dossier is composed of 154 pages recto and verso (that is more than three hundred pages); it started in 1555 and ended only eight years later. My article "Relazioni oltre le mura" 
The case would drag out until 1563 , and was closely followed by the young Cardinal Carlo Borromeo who, at the time, was the attentive governor of the region and thanks to whose involvement, probably, the documents ended up arriving in copy to and for the information of the Uffici del Tribunale del Cardinal Governatore di Roma. ${ }^{29}$ Within the three hundred plus documents of the Roman copy of the trial are conserved all of the passages and the comings and goings of testimonies and opinions that, in the course of eight years, ultimately enabled agreement upon a shared answer to this question: were Sara and Emanuel married, or did they only commit to an engagement? At first, the argument was heard in the form of rabbinical arbitration and then was passed, after the failure of the Jewish procedure, to the Christian courts, amidst a tangle of accusations of false assertions or of undermined testimonies. The words of twenty-seven testimonies, which included Jews, Christians, and three rabbinic arbiters, as well as the involvement of ecclesiastical authorities and of a pair of illustrious persons, did not obtain any result. The majority of those called to testify, in fact, clearly recalled how just and only an engagement had been involved, and agreed as well on the indisputable differences between the two ceremonies, which, moreover, were described in detail. As most maintained, the girl had merely nodded her consent to the engagement, and received the blessing of her parents, but no formula of marital commitment had been pronounced. The only opposing position was expressed by a certain David Caspi, a shifty character whose bad faith was proven beyond the shadow of doubt in 1561, thanks to the intervention of the new Christian convert Giacomo Giraldini, who was formerly Rabbi Joseph Arli, and was at the time the auditor of Hebrew books in Ferrara. ${ }^{30}$ The investigations that followed put

provides a detailed description of its development and biographical references to people who were involved in it. For a description of Jewish marriage in early modern Italy, see Roni Weinstein, Marriage Rituals, Italian Style. A Historical Anthropological Perspective on Early Modern Italian Jews (Leiden: Brill, 2004).

29 On Carlo Borromeo and the Jews, see Renata Segre, "Il mondo ebraico nel carteggio di Carlo Borromeo," Michael. On the History of the Jews in the Diaspora 1 (1972): 163-26o.

30 Di Nepi, "Attraverso le mura," 37-38. On Giraldini see Shlomo Simonsohn, The Apostolic See and the Jews. History (Toronto: Pontifical Institute of Medieval Studies, 1991), 28485, n. 138; Andrea Yaakov Lattes, "Gli ebrei di Ferrara e le imposte per i Catecumeni," $L a$ Rassegna Mensile di Israel 65, no. 3 (1999): 41-54, n. 10; di Leone Leoni, La nazione ebraica spagnola e portoghese: doc. 1154: 1027-1028; docc. 1185-1186: 1040, 10141; doc. 1559: 1168. In previous years, Iosef Arli da Siena, at the time when he was still a Jew and a rabbi, kept close contact with Rabbì Treves himself: Shlomo Simonsohn, "I banchieri da Rieti in Toscana," La Rassegna Mensile di Israel 38, no. 9 (1972): 406-23. For his work as censor, see now Piet van Boxel, "Hebrew Books and Censorship in Sixteenth-Century Italy," in Jewish Books and Their Readers, 75-99. 
a strain on Caspi-but not on those who presumably induced him to lie-that is, the groom and his family. With his retraction, which was given on 25 May 1561 in front of the final rabbinic triad and then sent in sworn translation to the Christian authorities that were following the case, the affair found its conclusion: Emanuel and Sara were never married, and therefore there was no get to celebrate nor gifts to return. ${ }^{31}$

The historical backdrop alone underlines the relevance of this case. The marriage was, in fact, arranged during the final days of the papacy of Julius III, when there was not yet any talk of ghettos, and the burnings of Marranos did not yet appear on the horizon. Yacob Belcayro changed his mind during the course of the following year, as attested to in the documents from between the autumn of 1555 and the winter of 1556 . Therefore, his rethinking occurred during the months in which the Jews of the Papal States completed their relocation into the newly instituted ghettos, and during which trials against Marranos began at Ancona. The final steps in the dispute came in 1563, after the publication of the bull Dudum felicis, which, at least in part, mitigated Carafa's provisions and that, for Ancona, seemed to signal a break with the dramatic period of the immolation and a return to the normal life that would follow it. The birth of the ghetto and the investigations of the Portuguese directly affected the Belcayro and Montolmo families, and it is possible that in some way they contributed to the undermining of the nuptial project. The father of the bride was the factotum for Francisco Barboso, the most important Portuguese banker in the city, who dramatically fled to Salonica while still remaining closely connected to the networks of Marranos. ${ }^{32}$ The family of the groom could also be found among the restricted circles of elite Jewish citizens: it is no accident that in February of 1556 Montolmo, while preparing to argue with his almost in-law Belcayro, was included among the members of the Jewish delegation that would negotiate with the bishop of the city regarding the promulgation of laws governing the renting of homes in the ghetto (to which we will return further below). ${ }^{33}$

$31 \quad$ Trial: $148 \mathrm{v}-152 \mathrm{r}$.

32 Luca Andreoni "Perché non se habbia più a tribulare.' Gli ebrei della Marca fra spazi economici e conflitti giudiziari alla metà del XVI secolo," in Caffiero, Esposito, eds., Gli ebrei nello Stato della Chiesa, 109-47; Bernard Dov Cooperman, "Portuguese Conversos in Ancona. Jewish Political Activity in Early Modern Italy," in Iberia and Beyond. Hispanic Jewry between Cultures, ed. Bernard Dov Cooperman (Newark: University of Delaware Press, 1998), 297-313.

33 National Archives for the History of Jewish People (Jerusalem), IT/ An 547, Strumenti, sentenze e documenti vari riguardanti la scuola italiana, Copia conferme dei Capitoli di Ancona prodotta su richiesta di Simone Gattegna procuratore seu Fattore dell'Università degli ebrei italiani nel 1616. 
Of all these affairs, which doubtlessly concerned the Jews in Italy and outside of Italy, not a word can be found in the trial. The explicit mention of the bull Dudum felicis in the summary is the only reference contained in the dossier concerning the evolution of the rules that regulated the presence of the Jews in the Papal States. ${ }^{34}$ The tensions that had gripped the community beginning in 1555 - between trial, immolation, and attempted boycott ${ }^{35}$ - do not appear in the course of the long debate, notwithstanding the contemporaneity of the events and the direct participation of some of the witnesses in many of them. This silence offers a glimpse of the reactions (and perhaps also of the emotions) of the Jews of Ancona to the double trauma through which they were living. According to the information reported in these documents, the ghetto and the condemnation of the Marranos represented issues in and of themselves, in some way marginal to the daily life of the Jews of Ancona and of their friends, acquaintances, and business partners in and out of Italy. It is worth advancing some hypotheses on these subjects, beginning precisely with the rules concerning the rents in Ancona.

The construction of the seraglio and the reorganization which followed it were considerable challenges for the community and its leaders, who made every effort to assure the Jews of the city an easy transition. The absence of a law and the disparity of conditions which the promulgation of the first privileges of the Levantine Jews in 1546 had established could possibly have created an irreparable rift between Italians, Levantines, and Ponentines. ${ }^{36}$ In the course of assigning the best homes as well as the reduction of some types of privileges vis-à-vis the authorities, social tensions between national and socialeconomic groups might have become unmanageable; it must be noted that

\footnotetext{
34 On this, see still Attilio Milano, Il ghetto di Roma (Roma: Carucci Editore, 1984), 71-78.

35 As is well known, Dona Gracia Nasì tried to organize a general blockade of the port of Ancona from Turkey, with the goal of applying pressure on the Pope in order to save the Marranos.

36 Cooperman, "Portuguese Conversos in Ancona." On Ancona and the Jews at this time and in addition to the works by Andreoni and by Cooperman, see also Giuseppe Laras, "Intorno al 'ius cazacà' nella storia del ghetto di Ancona," Quaderni storici delle Marche 7 (1968): 27-55; Viviana Bonazzoli, Adriatico e Mediterraneo orientale. Una dinastia mercantile ebraica del secondo '6oo: i Costantini (Lint: Trieste, 1998); id., "Sulla struttura familiare delle aziende ebraiche nella Ancona del '70o," in "La presenza ebraica nelle Marche. Secoli XIII-XX," ed. Sergio Anselmi andViviana Bonazzoli, Proposte e ricerche 14 (1993): 139-154; id., Commerciare nel ghetto. La società Oef-Magistri in Ancona a metà Seicento (Ancona: Archivio di Stato di Ancona, 2000). And now, Martina Mampieri, "Living Under the Evil Pope': Paul IV and the Jews in the Hebrew Chronicle by Benjamin Nehemiah ben Elnathan from Civitanova Marche (16th cent.)," PhD diss., Università degli Studi "Roma Tre"-Universität Hamburg, 2017. I am especially grateful to Dr. Mampieri for having permitted me to read her unpublished research.
} 
the Anconian groups worked intelligently to prevent this from happening. The draft of the previously cited document of 1556 regarding the regulation of rents, which was in complete agreement with the bishop of the city, was an essential instrument of this policy of cautious and organized adaptation to the transformations that were underway. ${ }^{37}$ The experiences of Venice and Ragusa, already decades old, had taught just how disruptive the question of housing was. Based on these precedents, the Jews of Ancona decided to create regulations, and to guarantee that these had the maximum legal force possible by ensuring the direct involvement of the Ecclesiastical authorities and the local government. The legislative plan followed for the ghetto of Ancona replicated, in part, that successfully applied in Rome with the Capitoli di Daniel da Pisa three decades earlier. Both at Rome in 1524 and Ancona in 1556, the successful negotiation of Jewish internal regulations depended on close collaboration between the Church and the Jewish leadership. The choices made in Rome between 1555 and 1556 confirm, if from an unusual perspective, this interpretation. In Rome, in fact, the presence of shared rules, which had been approved by the Pope personally and which had already survived the tests of the Sack of 1527 and the burning of the Talmud of 1553, made the opening of new negotiations with the Church a bad bet, if not dangerous. As at Rome, so too at Ancona there was, therefore, the elaboration of a political strategy for surviving the convulsive transformations and violent pressures of those years, taking account of precedents (between expulsions and ghettos) and aimed at keeping the community strong and united, at least in the eyes of the Ecclesiastical authorities. ${ }^{38}$

Generally speaking, furthermore, these Anconian capitoli add an element to the history of the close relations of the Adriatic city with Venice and Ragusa, whose already decades long experience was certainly taken as an example in the drafting of the text. ${ }^{39}$ Exchanges and contacts between the Jews of the city and other nations were not limited to the web of commercial and matrimonial networks but also encouraged the circulation of ideas, news, and models of behavior. The Belcayro-Montolmo case offers many confirmations along these lines, which aid in fully inserting Ancona, but more generally the Papal States as a whole, into the history of the Western Sephardic diasporas and of their multitude of networks, which were as much mercantile as they were, perhaps in a more elusive fashion, socio-cultural. The calculated removal of the Portuguese affair, so evident in the lengthy testimonies of this trial, illustrates the attitude of the Jews: having failed to save the unfortunates who had been

Strumenti, sentenze e documenti vari riguardanti la scuola italiana [...].

38 Di Nepi, Sopravvivere al ghetto, 29-33.

39 Ligorio, "Ragusa." 
investigated, and having put the boycott behind them, life resumed as beforeincluding continued relations with the Jews of the Ottoman Empire ${ }^{40}$ - and the entire business was filed away, with its unhappy memories. They had to move forward.

The Belcayro-Montolmo conflict unfolded precisely during this "move forward." The silence regarding the frightening events of the two-year period $1555^{-155^{6}}$ stands in contrast with the incessant chatter that accompanied all phases of the case. The trial developed around three lines of inquiry: the gathering of information about the contested and uncertain facts which had given rise to the case; a continuous search for information regarding the people who were involved; and the urgent task of unequivocally defining Jewish marriage customs, and of the subsequent comparison between those followed in Ancona, in other Italian cities, and even in Turkey. The words of the many testimonies which offered responses and opinions on these points carry with them a wealth of information about happenings in other places, which allows for the tracing of a map of the relations and the movements of Jews in the first years of the ghetto. At the center was Ancona, with its relationships with all of Jewish Italy and with the Adriatic, including, preponderantly, the Ottoman cities of Smyrna and Salonica. News circulated quickly in the vast network that connected, directly and indirectly, the Jews and the Christians (and also the converts) who in some way had something to do with Ancona. This polyphony of narratives determined the reputation of business partners, an intangible asset of inestimable value, one that could be created, modified, or destroyed by even an isolated rumor. The elusive and subjective terms of good and bad conduct contributed to the shaping of the space of intercultural commerce in the Adriatic, a space in which Jews, Catholics, Eastern Christians, and Muslims were contemporaneous actors ${ }^{41}$ It is in this context that one must view the appearance of Christian merchants at a trial concerning the breaking of a marriage agreement between Jews as much as the appearance of a description of the nuptial parties of the Jews of Turkey in an argument which was completely internal to the Italian community. In both cases, the main point is this: mobility, exchanges, and information built a far-reaching network of relations, which was not limited to this intercultural commerce but, rather, was strengthened

40 On Jews, Ancona, and the Ottoman areas, see Luca Andreoni, "Riscatto degli schiavi cristiani e intermediari ebrei. Un caso di studio tra Ancona e Ragusa (XVIII secolo)," Dimensioni e problemi della ricerca storica 2 (2013): 109-33.

41 Giuseppina Minchella, Frontiere aperte. Musulmani, ebrei e cristiani nella Repubblica di Venezia (XVII secolo) (Rome: Viella, 2016); Luca Andreoni, 'Una nazione in commercio.' Gli ebrei di Ancona (sec. XVI-XVIII)," PhD diss., University of San Marino, 2014. 
by it day after day. The story of David Caspi tells us something about these very subjects.

\section{Good versus Bad Jews}

It was the testimony of the illustrious convert Giacomo Giraldini that put David Caspi and his past under the spotlight. In the course of his interrogation, Giraldini first pointed out how the Montolmo's claims rested exclusively on the contrary testimony of this "Levantino" Jew. Then, in an attempt to bring this ambiguous character into focus, the Ferraran convert and auditor raised the stakes, bringing to light an old story of thefts in Venice in which Caspi had been involved. From that moment on, the trial entered a new phase, which was concentrated on profiling those involved in the case. On one side, there were the good Jews (Belcayro and his associates and Montolmo himself); on the other were the untrustworthy Jews, with obscure backgrounds; in other words, Caspi and those like him. The life and works of David de Caspi "hebreo levantino che habita in casa di Lazzaro di Zucharo"42 were attentively reviewed in many of the testimonies. The first stone was thrown by Giraldini himself, who would bring to light an old Venetian scandal, which he had heard about in Ferrara from a member of the prominent Abravanel family. A look back to the recent past allowed a reconstruction of this affair, which though distant both geographically and chronologically from the events in Ancona, proved to be essential for establishing who, and in whom one could trust, in a trial which revolved around the trust that could be placed in the words of the witnesses.

Three and a half years earlier, at Venice, Leone Abravanel, a Ferraran and son of the celebrated scholar Abravanel, found his home burglarized. ${ }^{43}$ Following the victim's complaint, a balio of the Republic publicly announced the crime at the Rialto Bridge, and offered a significant reward to anyone who would cooperate with the investigation into the disappearance of furniture and other items from the Abravanel home. Within a short period of time, one Coen of Corfu, also a Jew, gave the authorities the names of Mometto Calonimos and Moisè Todeschino, both of whom were by then missing, and both of whom had already for some months been the object of insistent rumors that placed them at the center of a network of illicit trafficking. The two fugitives, who were immediately banned from the territories of the Serenissima, would meet different fates. Mometto was arrested in Venice and sent for three years at the oar on the Republic's ships, after which he returned home free, thanks to the benevolent

42 Trial, 11v. List of witnesses in favor of Jacob Belcayro.

43 I am especially grateful to Professor Bernard Dov Cooperman for this identification. 
intercession of Abravanel himself, who, when made aware of the criminal's poor condition, renounced the compensation which he was owed. Todeschino, instead, as far as those in Ancona who had heard could recall, was captured in Ferrara where he was condemned to death. Once free, or perhaps before (the chronology is not clear), Mometto ended up being involved in another unpleasant incident, this time at Salonica, where, together with David Caspi, they stole containers of Anconian merchandise from customs, getting into trouble some of the very Anconian Jews who now-between 1560 and 1562 - could be found arguing over a marriage/engagement and restitution of gifts and dowry. ${ }^{44}$ The crime committed in Salonica helped to define Caspi, and definitively placed him alongside and as an accomplice of those he had helped in Turkey, who were at the moment in the Venetian galere, entangled in another equally disgraceful incident. Surrounded by such a negative reputation, David Caspi returned to the center of the collective attention when, as the only witness to swear to having attended the celebration of an actual wedding in February of 1555, he was dramatically exposed by the convert Giraldini, who, furthermore, was familiar with many of the stories that circulated about him and which were promptly presented in court.

A range of testimonies contributed to the assembling of a portrait of an untrustworthy and villainous man, presenting a pointed, and carefully calibrated list of the evil merchant's vices. The narration of David's life followed a pattern. It was said that he had been born to a good family in Salonica, and that his father had left him a thousand scudi but that, regardless of having inherited money, contacts and social position, he had preferred to associate with the wrong kind of people and that, due to this, he had survived only thanks to the charity of his coreligionists. ${ }^{45}$ His progressive social and economic decline resulted in a general condition of poverty, where, in addition to the lack of money were amoral behaviors: playing cards, and drinking and eating to excess, in open violation of every norm of good Jewish conduct. ${ }^{46}$

44 Trial, $68 \mathrm{v}$.

45 "Samuel Baruchus, hebreus orientalis" witness: "E' figliolo di un uomo da bene che era savio nella nostra legge ma lui è reputato tra noi per una mala persona et stando io pare che anni sono in Salonichio intesi pubblicamente che l'articulato Davit have levato dalla Dogana di quel luogo doi balli d'ostrafini et che quando li patroni andorno per volerle repigliar non ce le trovarono et così fu cercato et trovate a lui et gli furono rivolte altro non vi posso dire e ben vero che lui dopo questo fatto si partì da Salonichio ma non so per chè causa." Trial, 93r-v.

46 "David Codava hebreus orientalis" witness: "Davit e povero e mendico et di mala vita et fama et che qui si conosce che havenoli lassiati in Salonichio suo patre che era huomo di buona faculta per ottocento o mille ducati doppo la sua morte quel Davit si portato talmente nel giocare mangiare et bevere disordinatamente ch'ha sprecato ogni cosa et non ha più niente et di più per vender vera ragione della sua vita et qualità vi dico che 
On the contrary, Yacob Belcayro, a well-known rabbi and merchant, enjoyed an excellent reputation among Jews as well as Christians. The witnesses who were called to the bench after the unveiling of the hidden aspects of Caspi and his statements drew a portrait of Belcayro as the good merchant. "Samuel Baruchus, hebreus orientalis" spoke of Belcayro, relating stories of a lengthy patronage, and focusing on their mutual business and his standing as "a wealthy and reliable person of good conduct and attitude." ${ }^{\text {"7 }}$ The testimonies of the Christian merchants who did business with Belcayro were decisive. One after the other appeared in front of the court, attesting that they knew Belcayro personally and to have had friendly dealings with him in his dual roles as businessman and doctor. The five men- "Dominus Franciscus Gabriel civis anconitanus,"48 "Antonius Marghanettus civis Anconitanus," 49 "Dominus Antonius Maninus Anconitanus mercator,"50 "Nicolaus Barberinus

havendo lui fatto sposalitio in Salonichio con una hebrea deli intese ch'hebbe le qualita di costui non volse più et fu dismesso il parentato che accosi volsero li parenti della sposa che dall'anno ${ }^{155^{8}}$ poco prima o poi l'articulato Davit ho inteso che stando in Salonichio ando alla dogana et si piglio due balle d'ostrafini dicendo che erano li suoi et li porto via. Attalche andato il patrone per repigliarli trovò che non v'erano et così fu cercato contra esso Davit et gli furono ritolti et per bastardo spergiuro povero et persona di mala conditione e stato sempre et e di presenti fra tutti noi altri hebrei havuto temuto et reputato ed di presente s'hatiene et reputa publicamente." Trial, 8ov.

"Io ho conosciuto Jacob qui in Ancona di continuo et di continuo ho praticato et negoziato con lui diverse faccende mercantili et in tutto questo tempo ho trovato persona di buona condizione pro bono reale et de bene per tale et come tale pubblicamente si tiene et reputa da noi altri hebrei così levantini come italiani che lo conoscono." Trial, 92r.

48 "Pratica et conversatione et ho fatto con lui varie faccende mercantili di dar et havere et sempre per hebreo lo trovato et esperimentato buon da bene giusto et reale in tutte le sue attiene $[. .$.$] mi impicciarei più tosto con lui che con qual si voglia altro hebreo del mondo$ $[\ldots]$ in questa città è stato sempre come medico havuto tenuto et riputato tra quegl'huomin et mercanti di Ancona." Trial, 112r.

49 "Io ho avuto da fare con lui per conto di mercanti nel dar et nell'haver et sempre io l'ho conosciuto et trovato huomo da bene per hebreo reale et fidele di buona condizione et vita ne mai nella nostra cosa ce stata una discrepanza ne per un minimo contrasto che lui con me e andato tanta realmente sempre quant'altro persona ch'habbi mai praticato in tempo della mia vita et per per la sua fidelità et buona natura nelle mie faccende mi fiderei si di lui come di qual si voglia altra persona et pure questi di passati senza altra scrittura [...] Mi sono fidato di lui di scudi cento et otto non mi sono securato d'altra cautela ma me ne son stato sopra la sua parola perche buono che non mancherebbe mai di quanto promette et a me mi e riuscito sempre così come mediche e noto me ho mai intesa che abbia fatto comunella ne altra cosa brutta et per tale et per tale et come tale in questa città tra noi altri gentilhuomini et mercanti e stato sempre havuto, tenuto et reputato per tutto questo tempo et di presente s'hatiene et reputa con Salamon da Cagli." Trial, 113v-114v (my emphasis).

$5^{0}$ "Et in questa città per mercanti et altre genti è in buonissimo conto et credito et volentieri mi sono impicciato et mi impicciarei ancora con lui [...] Tutti lo conoscono specialmente 
civis Florentine mercator Anconae,"51 and "Simone Ranuccinus mercator Florentinus Anconae degens"52_ confirmed the universal esteem which the Jew enjoyed among the merchants of the city (and also outside of it) and his full membership among the elites who in Ancona controlled both the traffic of merchandise along the Italian peninsula as well as the international commerce that crossed the eastern Mediterranean in every direction. Antonius Marghanettus and Nicolaus Barberinus had actually done business with him for years based solely on his word, without putting the agreements in black and white before a notary and notwithstanding the fact that the merchandise had to travel outside of the Papal States. The phrase "freely without documents" implied that the parties operated in an environment of reciprocal and unconditional trust, capable of withstanding the jar of a legal controversy, which evidently was considered improbable. In the event of a dispute, in fact, it would have been difficult to prove the case of one or the other, and it would have ended up involving their circle of friends and acquaintances, just as was happening around Belcayro and Montolmo, perhaps with negative consequences for the good reputations of the parties.

Therefore, the full and undisputed inclusion of Belcayro and of few others in the restricted group of Jews who might be called "persona bonae conditionis et famae inter ipsos hebraeos pacifica et quieta aliena delictis" - according to the Latin formula used by the defense lawyer - passed for the intercultural attestation of his trustworthiness. The processes of building a good reputation in the Mediterranean contact zone simultaneously concerned Jews, Christians, and Muslims, who were residents on one coast or the other, and in continuous movement between Christian and Muslim territories. As has been seen with regard to David Caspi, this uninterrupted circulation of things, news, and people fostered the overcoming of rigid social and confessional divisions, which in theory must have distinguished one from the others. The proper functioning of the economic networks rested upon the trustworthiness of the parties involved. The physical motions of give and take were made possible by the trust placed in the counterpart, both to those known in person or, instead, via the guarantee offered by a third party. Within the small zone of the Adriatic of the third quarter of the 1500s, devastated by the consequences of the burning

fra noi mercanti sloggia con lì quali pratica di continuo per il suo ufficio della senseria et di tutto questo ch'io vi dico n'è pubblica nova et fama et pubblico et notorio qui in Ancona massime tra quelli ne hanno pratica con lì ditti Jaacob et Salamone et li conosco tanto più tra mercanti." Trial, $116 \mathrm{r}-117 \mathrm{r}$.

$5^{1}$ As they had been friends and business partners for years, he sent him to Pesaro "senza scrittura." Trial, 119v (my emphasis). 
of the Marranos in Ancona, news traveled quickly. In an already tense political and military environment, every scrap of information carried weight. To remain within the limits of the Belcayro trial from which we began, Caspi's "bad reputation," over and over again confirmed by the Jews, rendered him persona non grata in Salonica, as well as among the Christian merchants and groups of Muslims, to the point that he was forced to try his luck in Italy. In Italy, however, his broken engagement in Salonica in 1558 was well known, and the business of the fabrics which had been taken from customs illegally had also not been forgotten; it is no accident that some years later Caspi was found to be involved, even if only at the level of gossip, in the crimes against the Abravranels in Venice. As the Jews repeated, Caspi, and those like him, could not be trusted.

The "good Jews" and the "bad Jews" built their fortunes within the group and found validation outside it. ${ }^{53}$ In one case as in another, one necessarily proceeded in concentric circles, and the first word belonged, as was the nature of things, to the group closest to the subject. The osmosis between inside and outside did the rest: a Jew in good relations with other Jews came across in the best possible way outside the Jewish world; a Jew in good relations with the surrounding society could strengthen and consolidate his reputation and consequent position within the group. ${ }^{54}$ The question of what defined a good Jew and what conduct was expected of those who wished to fully bear the title of "good Jew" once again suggests the need, and a methodology, for a thorough investigation of the majority-minority relations within the porous spaces of the Italian ghettos. In this context, identifying the boundaries between what is exclusively within the ghetto and that which takes place exclusively outside the ghetto becomes extremely complex. The Belcayro-Montolmo case is clear proof of this. A dispute between Jews, born around a Jewish ceremony, which focused on the correctness of the formulas that were imposed on the Jews for swearing oaths, was ultimately resolved thanks to the opinions of Christians with whom these Jews had relations, and by a convert, all of this taking place during years in which the laws separating the one from the other should have indicated prudence, at least in Ancona, the city of the immolation. For the participants in the trial, the institution of the ghettos certainly did not interrupt the exchanges and interactions between Jews and Christians, notwithstanding the fact that they lived in one of the communities most impacted by Carafa.

53 On bom judesmo as a social, cultural and political tool, see Kaplan, An Alternative Path to Modernity, 108-94.

54 On Rome, in the same period and in a very similar situation, Di Nepi, Sopravvivere al ghetto, $15^{-205}$. 
The affair in Ancona, with its Roman vestiges and its national and international connections, illuminates the years of the birth of the ghettos from an unprecedented perspective, starting from the city of the immolation. The calculated absence of any reference to the transformations of 1555 and the tragic events of 1556 cannot be underestimated. If, on the level of the sentiments of the Jews who were directly and indirectly swept up in the storm, one can and should form conjectures that revolve around the individual and collective responses to the upheavals in progress, or attitudes of prudence in a phase of disruptive reassessment, perhaps, from a broader perspective, other and more general hypotheses can be advanced. The Belcayro vs. Montolmo case, for example - with its lengthy duration (eight years are a lot for a hearing about an engagement) and its vast geographical backdrop-suggests more general interpretations. The Anconian testimonies, which were collected several times by Jewish arbiters and Christian judges between 1555 and 1563, and which involved people of various faiths and innumerable provenances, tell a story about the ghetto even without ever explicitly mentioning it, and allow a wider view outside of the specific case being discussed. We will try to see how.

On the level of majority-minority relations, the trial narrates the story of a revolution avoided. The reshaping of Jewish spaces which followed the promulgation of Cum nimis absurdum forced Jews and Christians to reorganize these relations, but did not succeed in breaking them (and probably was not meant to). Business partnerships and interpersonal relationships survived without great difficulty and, in the specific case of Ancona, continued their progress on a daily basis and with success in the wide and intertwined space of the Christian-Ottoman Adriatic. The processes of establishing good and bad reputations as they are presented in the documents of this dispute, after all, seem to me to speak for themselves.

At the individual level, men and women were asked to change residences in order to concentrate in the traditional Jewish quarters, which had a serious impact on that part of the population that had homes and shops in other parts of the city. In this case as well there are stories about which we do not know enough and, given the current state of research, of which it is possible to look at only a few small aspects that are known with certainty, and which suggest looking at the pontificate of Carafa as the beginning of a slow transformation. Regarding the living conditions of the Jews in the ghettos and the resettlement of the Jewish population, the partial expulsions by Pius $\mathrm{v}$ in 1569 and then by Clement VIII in 1593 would weigh even more heavily, and, by definitively limiting the permanent residence of the Jews of the Papal States to the ghettos of 
Rome, Ancona, and Avignon, resulted in the concentration of the entire Jewish population of the State into a few hundred square meters. However, at this juncture as well, the resettlement, as defined on paper after 1593, did not lead to the disappearance of Jews from the rest of the territory. ${ }^{55}$ Even after the final restrictions of Pope Aldobrandini, Jews continued to live and work in cities that had no ghetto, taking advantage of the ambiguous rules and jurisdictional overlaps that were typical of an institutional system of the Old Regime. A map showing the points of this Jewish life outside the walls and without ghettos in the Papal States would surely allow a more precise definition, outside of rhetorical schemes, of the place of the ghettos in the modern era. For now, it is sufficient to note how the erection of the enclosures did not interfere with either the individual mobility of the Jews or, even less, with the relations between Jews in the ghettos and Jews on the outside. Thus, the result was a metamorphosis more than a revolution.

On the professional level as well, it should be recalled that the requirement of Jews to adapt their professional activities to the limits prescribed by the bull left intact for all of the 1500 and most of the following century the lending and trade that were the heart of Jewish business. Likewise, in this case, the most significant changes would arrive later: for Rome after the suppression of the Jewish banks in 1682 and for Ancona, perhaps, never in so radical a fashion. The documentation contains innumerable signs in this direction, which clearly indicate how, exactly, definitions of the ghetto as a physical space of identity that was closed and complete in and of itself must be rethought despite the serious discriminations, while not ever forgetting them. A separation over a long period of time resulted, which certainly brought about a profound adaptation, but which never implied a condition of absolute isolation or, even less, a definition of the Jews as foreign. The Jewish condition existed, somehow, in a vague space when it came to the lines of citizenship (so complex to determine in this period) and of inclusion, which were always achievable via conversion, an option that was certainly available to the Jews but rarely used: it was an apartness regulated by rules which were known and subject to some variation, which created for the Jews, their experiences, their lives, and their customs a familiar otherness.

The business of the ghetto had, however, more protagonists: the ghettoized Jews, the Christians who lived and worked around them, the popes who wanted

55 It should be noted that when Sixtus v again admitted Jews in the Papal States, Jewish families decided to come back to the previous areas of residency or to settle in new zones: Archivio di Stato di Roma, Camerale I, Diversorum del camerlengo, r. 394: Introitus cum habitatione: 6 or/73v. 
to ghettoize them. In the background, for Paul IV, his predecessors, and successors was the Church's traditional objective of the universal conversion of the Jews. In the first place, however, the facts and challenges of the moment had to be taken into consideration, and these help us to understand the reasons for Carafa's declination of classic Catholic eschatology. While this doubtlessly constitutes a central element of papal policy towards the Jewish minority dating back to Augustine and Gregory Magno, this watershed moment in the 1500 also calls other aspects into question. Once again, the Belcayro versus Montolmo dispute offers points for reflection. On the one hand, the discrepancy between what the trial tells us about the daily life of the Jews of Ancona (national and international networks, close and trusting relations with Christians across the peninsula, continuous news from the outside and from the Ottoman Empire) and the major events of which there are no mention (ghetto and immolation), brings to light the continuation of a lifestyle which we have discussed above. On the other hand, these three hundred documents cause one to wonder what the Pope was really trying to do when deciding to raise walls in the Papal States forty years after the creation of the Venetian institution (in a markedly different key), and immediately afterwards launching a ferocious investigation of conversos, who had prospered undisturbed in Ancona for some time already. That Carafa had little love for the Jews is beyond question; that his choices regarding the subject oscillated between different positions is as well. On the one hand — and first of all — the institution of the ghettos, for all their well-known limitations and ambiguities, offered welcome; on the other, persecution and violence, which indicated, instead, a completely different direction. In other words, one might say, there was the way of Venice and Ragusa, and the Iberian approach. Two opposing poles, but together the bearers of a precise political significance in the Italy of those years and, above all, during the papacy of Paul IV, the last pope to make war against the Hapsburgs and to seek, by any means, to thwart Spanish dominance on the Italian peninsula. ${ }^{56}$ It leads one to question whether if in his choices regarding the Jews, made immediately after his enthroning, it is also possible to read a message directed at his allies - that is to Venice and to France - and to his enemies - which is to say Charles v and Phillip II. And that message, drafted at a Council already in session, at the height of the final stage of the Franco-Imperial wars, after the peace of Augusta (1555), of which the Pope greatly disapproved, but

56 Iberian Kings ordered the "Last Spanish expulsion" at the end of the century and after the signature of peace agreements in both Italy (1559) and Germany (1555). See Flora Cassen, "The Last Spanish Expulsion in Europe: Milan, 1565-1597," AJs Review 38, no. 1 (2014): $59-88$. 
before the peace of Cateau Cambresis (1559), could have gone like this: the last word on the governing of faith and the faithful belonged to the one and only Catholic sovereign, the Pope, who ruled based on history and traditions, and that because of this, when it came to the hot and always delicate subject of the Jews, he had explicitly chosen the path of "tolerance." Meanwhile, however, at Ancona there would once again be a reminder of how this tolerance had its clear limits in baptism, however celebrated, and always held to be valid. For their part, the Jews of Italy read clearly between those lines, continuing to live their lives in the Papal States and drawing, as much as was possible, a firm line of demarcation between before (and its unrests) and after. Just as Manuello Montolmo, Yacob Belcayro, and their friends and acquaintances all did, they resumed doing business, communicating, and traveling, notwithstanding the revolutions that they had witnessed.

\section{Bibliography}

Allegra, Luciano. Identità in bilico. Il ghetto ebraico di Torino nel Settecento. Turin: Zamorani Editore, 1996.

Andreoni, Luca. "Perché non se habbia più a tribulare.' Gli ebrei della Marca fra spazi economici e conflitti giudiziari alla metà del XVI secolo." In Gli ebrei nello Stato della Chiesa. Insediamenti e mobilità. Edited by Marina Caffiero and Anna Esposito, 109-47. Padova, Esedra Editrice: 2013.

Andreoni, Luca. "Riscatto degli schiavi cristiani e intermediari ebrei. Un caso di studio tra Ancona e Ragusa (XVIII secolo)." Dimensioni e problemi della ricerca storica 2 (2013):109-33.

Andreoni, Luca. "Sono molto delicati li Ebrei di questo ghetto." Conversioni e strategie di difesa degli ebrei ad Ancona e nella marca pontificia (secoli XVII-XVIII)." Materia Giudaica 19 (2014): 291-302.

Andreoni, Luca. "Una nazione in commercio.' Gli ebrei di Ancona (sec. XVI-XVIII)." $\mathrm{PhD}$ diss., University of San Marino, 2014.

Andreoni, Luca, ed., Ebrei nelle Marche. Fonti e ricerche (secoli XV-XIX). Ancona: Il lavoro editoriale, 2012.

Berger, David. "Cum Nimis Absurdum and the Conversion of the Jews." The Jewish Quarterly Review 70, no. 1 (1979): 41-49.

Bonazzoli, Viviana. Adriatico e Mediterraneo orientale. Una dinastia mercantile ebraica del secondo '6oo: $i$ Costantini. Lint: Trieste, 1998.

Bonazzoli, Viviana. Commerciare nel ghetto. La società Oef-Magistri in Ancona a metà Seicento. Ancona: Archivio di Stato di Ancona, 2000. 
Bonazzoli, Viviana. "Sulla struttura familiare delle aziende ebraiche nella Ancona del '700." In "La presenza ebraica nelle Marche. Secoli XIII-XX." Edited by Sergio Anselmi and Viviana Bonazzoli, Special Issue. Proposte e ricerche 14 (1993): 139-54.

Bonfil, Robert. "How Golden Was the Age of Renaissance in Jewish Historiography?" In Cultural Change among the Jews of Early Modern Italy. Farnham: Ashgate, 2010.

Bonfil, Robert. Rabbis and Jewish Communities in Renaissance Italy. Oxford: Oxford University Press, 1990.

Bonora, Elena. Aspettando l'imperatore. I prinicipi italiani tra il papa e Carlo V. Turin: Einaudi, 2014.

Caffiero, Marina. Forced Baptism. Histories of Jews, Christians and Converts in Papal Rome. Berkeley: University Press of California, 2012.

Caffiero, Marina. Legami pericolosi. Ebrei e cristiani tra eresia, libri proibiti e stregoneria. Turin: Eianudi, 2012.

Caffiero, Marina. Storia degli ebrei nell'Italia moderna. Rome: Carocci, 2015.

Caffiero, Marina, and Anna Esposito, eds. Gli ebrei nello Stato della Chiesa. Insediamenti e mobilità (secoli XIV-XVIII). Padua: Esedra Editrice, 2012.

Caffiero, Marina, and Serena Di Nepi. "The Relationship between Jews and Christians. Toward a Redefinition of the Ghetto. Introduction to Special issue, Rivista di Storia del Cristianesimo 14, no. 1 (2017): http://primolevicenter.org/printed-matter/ not-that-ghetto/.

Caffiero, Marina, and Serena Di Nepi, eds. "I ghetti nell'Italia moderna." Special issue, Rivista di Storia del Cristianesimo 14, no. 1 (2017).

Calabi, Donatella. Venezia e il ghetto. Cinquecento anni del recinto degli Ebrei. Turin: Bollati Boringhieri, 2016.

Cassen, Flora. "The Last Spanish Expulsion in Europe: Milan, 1565-1597." AJs Review 38, no. 1 (2014): 59-88.

Chayes, Evelyne, and Giuseppe Veltri. Oltre le mura del ghetto. Accademie, scetticismo e tolleranza nella Venezia barocca. Palermo: New Digital Press, 2016.

Cooperman, Bernard Dov. "Ethnicity and Institution Building among Jews in Early Modern Rome." AJs Review 30 (2006): 119-45.

Cooperman, Bernard Dov. "Licenses, Cartels, and Kehila. Jewish Moneylending and the Struggle against Restraint of Trade in Early Modern Rome." In Purchasing Power. The Economics of Modern Jewish History. Edited by Rebecca Kobrin and Adam Teller, 27-45. Philadephia: University of Pennsylvania Press, 2015.

Cooperman, Bernard Dov. "Portuguese Conversos in Ancona. Jewish Political Activity in Early Modern Italy." In Iberia and Beyond. Hispanic Jewry between Cultures. Edited by Bernard Dov Cooperman: 297-313. Newark: University of Delaware Press, 1998.

Davide, Miriam, and Ioly Zorattini, Pietro, eds. Gli Ebrei nella storia del Friuli Venezia Giulia. Una vicenda di lunga durata. Florence: Giuntina, 2016. 
Davis, Robert C., and Benjamin Ravid, eds. The Jews of Early Modern Venice. Baltimore and London: Johns Hopkins University Press, 2001.

di Leone Leoni, Aron. La nazione ebraica spagnola e portoghese di Ferrara (1492-1559). I suoi rapporti col governo ducale e la popolazione locale ed $i$ suoi legami con le nazioni portoghesi di Ancona, Pesaro e Venezia. Edited by Laura Graziano Secchieri. Florence: Olschki, 2011.

Di Nepi, Serena. “Relazioni oltre le mura. Un processo ad Ancona all'epoca dei ghetti (1555-1563)." Special issue, Rivista di Storia del Cristianesimo 14, no. 1 (2017): 27-48.

Di Nepi, Serena. Sopravvivere al ghetto. Per una storia sociale della comunità ebraica nella Roma del Cinquecento. Rome: Viella, 2013.

Esposito, Anna. "Conflitti interni alla comunità ebraica di Roma tra Quattro e Cinquecento." In Judei de Urbe. Roma e i suoi ebrei: una storia secolare. Edited by Marina Caffiero and Anna Esposito: 69-79. Rome: Ministero per i Beni e le Attività Culturali, 2011.

Esposito, Anna. "Gli ebrei di Roma prima del ghetto: nuovi spunti." In Monaci, ebrei, santi. Studi per Sofia Boesch Gajano. Edited by Antonio Volpato: 377-94. Rome: Viella, 2008.

Esposito, Anna. "The Sephardic Communities in Rome in the Early Sixteenth Century." Imago temporis. Medium Aevum 1 (2007): 177-85.

Esposito, Anna. Un'altra Roma. Minoranze nazionali e comunità ebraiche tra Medioevo e Rinascimento. Rome: Il Calamo, 1995.

Ferrara, Micol. Dentro e fuori dal ghetto. I luoghi della presenza ebraica a Roma tra XVI eXIX secolo. Milan: Mondadori Università, 2015.

Foa, Anna. "Il nuovo e il vecchio: l'insorgere della sifilide (1494-1530)." Quaderni storici 19, no. 55 (1984): 11-34.

Foa, Anna. "La prospettiva spagnola: il Papa e gli ebrei nell'età di Carlo V." In L'Italia di Carlo V. Guerra, religione e politica nel primo Cinquecento. Edited by Francesca Cantù and Maria Antonietta Visceglia: 509-22. Rome: Viella, 2003.

Foa, Anna. The Jews of Europe after the Black Death. Berkeley and Los Angeles: University of California Press, 2000.

Foa, Anna. "Un vescovo marrano: il processo a Pedro de Aranda." Quaderni storici 99 (1998): 533-51.

Frattarelli Fisher, Lucia. Vivere fuori dal ghetto. Ebrei a Pisa e Livorno (secc. XVI-XVIII). Turin: Zamorani Editore, 2008.

Gasperoni, Michael. "Note sulla popolazione del ghetto di Roma in età moderna: lineamenti e prospettive di ricerca." In Gli abitanti del ghetto. La descriptio hebreorum del 1733. Edited by Angela Groppi, 69-115. Rome: Viella, 2014.

Groppi, Angela, ed. Gli abitanti del ghetto. La descriptio hebreorum del 1733. Rome: Viella, 2014. 
Hacker, Joseph R., and Adam Shear, eds. The Hebrew Book in Early Modern Italy. Philadelphia: University of Pennsylvania Press, 2011.

Ioly Zorattini, Pier Cesare, ed., Processi del S. Uffizio di Venezia contro ebrei e giudaizzanti. Florence: Olschki, 1980-1999.

Ioly Zorattini, Pier Cesare, Michele Luzzati, and Michele Sarfatti, eds., Studi sul mondo sefardita. In memoria di Aron Leoni. Florence: Olschki, 2012.

Kaplan, Yosef. An Alternative Path to Modernity. The Sephardic Diaspora in Western Europe. Leiden: Brill, 2000.

Kaplan, Yosef, ed., The Dutch Intersection. The Jews and the Netherlands in Modern History. Leiden: Brill, 2008.

Laras, Giuseppe."Intorno al 'ius cazacà' nella storia del ghetto di Ancona." Quaderni storici delle Marche 7 (1968): 27-55.

Lattes, Andrea Yaakov. "Gli ebrei di Ferrara e le imposte per i Catecumeni." La Rassegna Mensile di Israel 65, no. 3 (1999): 41-54.

Ligorio, Benedetto. "Ragusa. Un ghetto solo mercantile in Adriatico orientale (15461667)." Special issue, Rivista di Storia del Cristianesimo 14, no. 1 (2017): 53-70.

Luzzati, Michele. "Banchi e insediamenti ebraici nell'Italia centro-settentrionale fra tardo Medioevo e inizi dell'Età moderna." In Storia d'Italia, Annali 11, Gli ebrei in Italia. Edited by Corrado Vivanti. Vol. 1. Dall'alto Medioevo all'età dei ghetti: 175-235. Turin: Einaudi, 1996.

Luzzati, Michele. La casa dell'ebreo. Saggi sugli ebrei a Pisa e in Toscana nel Medioevo e nel Rinascimento. Pisa: Nistri Lischi, 1985.

Luzzati, Michele. "Una famiglia e quattro cognomi toponimici nel corso di un secolo: contributo alla storia degli ebrei d'Italia nel tardo Medioevo in una prospettiva interlocale." In Quel mar che la terra inghirlanda. In ricordo di Marco Tangheroni. Edited by Franco Cardini and Maria Luisa Ceccarelli Lemut: 469-77. Pisa: Pacini 2007.

Luzzati, Michele, and Giuliano Lazzarini. “L'orizzonte 'italiano' di una famiglia ebraica laziale: prime note sui da Toscanella." In Gli ebrei nello Stato della Chiesa. Insediamenti e mobilità, secc. XIV-XVII. Edited by Marina Caffiero and Anna Esposito: 51-62. Padua: Esedra, 2012.

Mampieri, Martina. "Living Under the Evil Pope': Paul IV and the Jews in the Hebrew Chronicle by Benjamin Nehemiah ben Elnathan from Civitanova Marche (16th cent.)." PhD diss., Università degli Studi "Roma Tre"-Universität Hamburg: 2017.

Mandelbrote, Scott, and Joanna Weinberg, eds. Jewish Books and Their Readers. Aspects of the Intellectual Life of Christians and Jews in Early Modern Europe. Leiden: Brill, 2016.

Milano, Attilio. "I Capitoli di Daniel da Pisa e la comunità di Roma." La Rassegna Mensile di Israel 10, nos. 7-8 (1935): 324-38 and 10, nos. 9-10 (1936): 409-26. 
Milano, Attilio. Il ghetto di Roma. Rome: Carucci Editore, 1984.

Minchella, Giuseppina. Frontiere aperte. Musulmani, ebrei e cristiani nella Repubblica di Venezia (XVII secolo). Rome: Viella, 2016.

Melcer Padon, Nourit. "Free Jews in a Free Port City: Livorno, The City without a Ghetto." Special issue, Rivista di Storia del Cristianesimo 14, no. 1 (2017): 71-88.

Novoa, James Nelson. Being the Nação in the Eternal City. New Christian Lives in Sixteenth-Century Rome. Peterborough (Ontario): Baywolf, 2014.

Pellegrini, Paolo, ed. Presenza ebraiche in Umbria dal Medioevo all'età contemporanea. Perugia: Editoriale Umbra, 2017.

Procaccia, Micaela.“' Non dabarà.' Gli ebrei di Roma nelle fonti giudiziarie della prima metà del Cinquecento." In Italia Judaica VI, Gli ebrei nello Stato Pontificio fino al Ghetto (1555). 80-93. Rome: Ministero per i Beni e le Attività Culturali, 1998.

Ravid, Benjamin. "Cum Nimis Absurdum and the Ancona Auto-da-Fé revisited: their impact on Venice and Some Wider Reflections." Jewish History 26 (2012): 85-100.

Ruderman, David. Early Modern Jewry. A New Cultural History. Princeton, NJ: Princeton University Press, 2010.

Ruspio, Federica. La nazione portoghese. Ebrei ponentini e nuovi cristiani a Venezia. Turin: Zamorani, 2007.

Savy, Pierre. "Entre peuple et communauté: remarques sur l'idée de nation chez les Juifs d'Italie (XV $\mathrm{e}-\mathrm{XVI}{ }^{\mathrm{e}}$ siècles)." Revue de l'histoire des religions 234, no. 2 (2017): 297-314.

Savy, Pierre. "Les 'politiques juives' en Italie du Nord avant les ghettos." In Religious Minorities, Integration and the State. État, minorités religieuses et integration. Edited by Ivan Jablonka, Nikolas Jaspert, Jean-Philippe Schreiber and John Victor Tolan, 35-47. Turnhout: Brepols, 2016.

Schwarzfuchs, Simon. "Controversie nella Comunità di Roma agli inizi del secolo XVI." In Scritti in memoria di Enzo Sereni. Edited by Daniel Carpi, Attilio Milani, and Umbero Nahon, 95-100 (Italian part). Jerusalem: Fondazione Sally Mayer, 1970.

Scuro, Rachele. "La presenza ebraica a Vicenza e nel suo territorio nel Quattrocento." Reti medievali rivista 6, no. 1 (2005): http://www.rm.unina.it/rmebook/dwnld/ebrei/ Ebrei_07_Scuro.pdf.

Segre, Renata. "Il mondo ebraico nel carteggio di Carlo Borromeo." Michael. On the History of the Jews in the Diaspora 1 (1972): 163-26o.

Segre, Renata. "La Controriforma: espulsioni, conversioni, isolamento." In Storia d'Italia, Annali 11, Gli ebrei in Italia. Edited by Corrado Vivanti, t. I, Dall'alto Medioevo all'età dei ghetti: 709-78. Turin: Einaudi, 1996.

Segre, Renata, ed. The Jews in Piedmont. Jerusalem: The Israel Academy of Sciences and Humanities: 1986-1990. 
Siegmund, Stephanie. The Medici State and the Ghetto of Florence. The Construction of an Early Modern Jewish Community. Stanford: Stanford University Press: 2006.

Simonsohn, Shlomo. "I banchieri da Rieti in Toscana." La Rassegna Mensile di Israel 38, no. 9 (1972): 406-23.

Simonsohn, Shlomo. The Apostolic See and the Jews. History. Toronto: Pontifical Institute of Medieval Studies, 1991.

Simonsohn, Shlomo. The Jews in the Duchy of Milan. 4 vols. Jerusalem: The Israel Academy of Science and Humanities: 1982-1986.

Simonsohn, Shlomo. The Jews in Sicily. 18 vols. Leiden: Brill 1997-.

Stefani, Piero. L'antigiudaismo. Storia di un'idea. Rome-Bari: Laterza, 2004.

Stow, Kenneth R. Catholic Thought and the Papa Jewry Policy. New York: The Jewish Theological Seminar of America: 1977.

Stow, Kenneth R. "Ethnic Rivalry or Melting Pot: The 'Edot' in the Roman Ghetto." Judaism 41 (1992): 286-96.

Stow, Kenneth R. "Prossimità o distanza: etnicità, sefarditi e assenza di conflitti etnici nella Roma del sedicesimo secolo." La Rassegna Mensile di Israel 58, nos. 1-2 (1992): $61-74$.

Stow, Kenneth R. Theater of Acculturation. The Roman Ghetto in the 16th Century. Seattle, London: University of Washington Press, 2011.

Stow, Kenneth R., ed., The Jews in Rome, 1536-1551. Leiden: Brill, 1995-1996.

Toaff, Ariel. "Gli ebrei a Roma”. In Storia d'Italia, Annali n, Gli ebrei in Italia. Edited by Corrado Vivanti. Vol. 1. Dall'alto Medioevo all'età dei ghetti: 123-52. Turin: Einuadi, 1996.

Toaff, Ariel. Il vino e la carne. Una comunità ebraica nel Medioevo. Bologna: Il Mulino, 1989.

Toaff, Ariel. "Lotte e fazioni tra gli ebrei di Roma nel Cinquecento." Studi romani 27 (1979): 25-32.

Toaff, Ariel, ed., The Jews in Umbria. Leiden: Brill, 1992-1994.

Todeschini, Giacomo. La banca e il ghetto. Una storia italiana. Rome-Bari: Laterza, 2016.

Toniazzi, Mafalda. I Da Camerino: una famiglia ebraica italiana fra Trecento e Quattrocento. Teramo: Palumbi, 2015.

Trivellato, Francesca. The Familiarity of Strangers. The Sephardic Diaspora, Livorno, and Cross-Cultural Trade in the Early Modern Period. New Haven: Yale University Press, 2010.

Urbani, Rossana, and Guido N. Zazzu, eds. The Jews in Genoa. Leiden: Brill, 1999.

van Boxel, Piet. "Hebrew Books and Censorship in Sixteenth-Century Italy." In Jewish Books and Their Readers. Aspects of the Intellectual Life of Christians and Jews in 
Early Modern Europe. Edited by Scott Mandelbrote and Joanna Weinberg, 75-99. Leiden: Brill, 2016.

Veronese, Alessandra. "Michele Luzzati e la storia degli ebrei come specchio della storia medievale." In "Diversi angoli di visuale" fra storia medievale e storia degli ebrei. In ricordo di Michele Luzzati. Edited by Anna Maria Pult Quaglia and Alessandra Veronese, 59-71. Pisa: Pacini Editore, 2016.

Veronese, Alessandra. Una famiglia di banchieri ebrei tra XIV e XVI secolo. I da Volterra: reti di credito nell'Italia del Rinascimento. Pisa: E TS, 1998.

Weinstein, Roni. Marriage Rituals, Italian Style. A Historical Anthropological Perspective on Early Modern Italian Jews. Leiden: Brill, 2004. 